\title{
FILSAFAT ISLAM
}

Tugas Mata Kuliah : Peran Filsafat Islam Dalam Dunia Modern

Dosen : Muhammad Arsyam, S.Pd.I., M.Pd

Email : arsyam0505@gmail.com

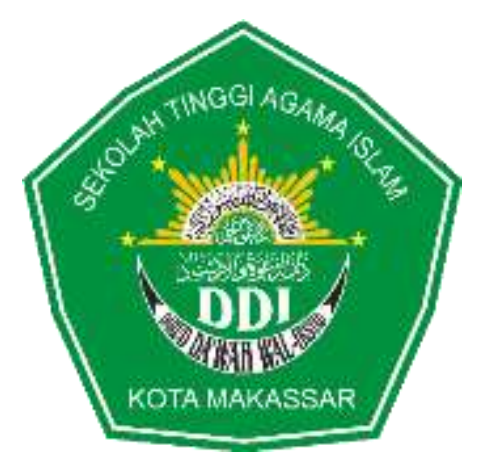

Oleh Kelompok 1

Nama : Dewi Sara / dewisara0595@gmail.com

Nim/nimko : 161100

Nama : Indriani Idris / indriallah99@gmail.com

Semester : V (Lima)

Jurusan : Syariah

SEKOLAH TINGGI AGAMA ISLAM

DARUD DAK'WA WAL- IRSYAD (STAI-DDI)

M A K A S S A R

2018 


\section{DAFTAR ISI}

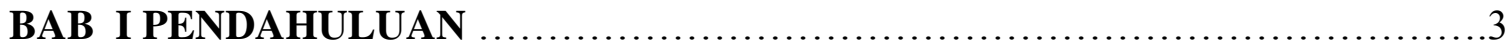

1.1 Latar belakang......................................................

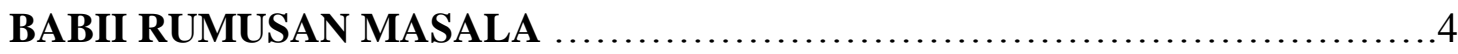

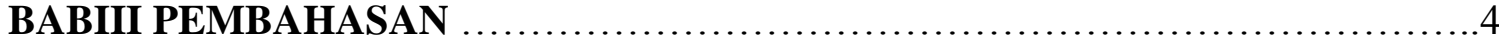

2.1PengertianFilsafat Islam $\ldots \ldots \ldots \ldots \ldots \ldots \ldots \ldots \ldots \ldots \ldots \ldots \ldots \ldots \ldots, \ldots 5$

1.ApaItu Filsafat Islam................................................5

2.PeranFilsafat Islam Dalam Dunia Modern.................................7

3.FilsafatIslam Di Indonesia...........................................9

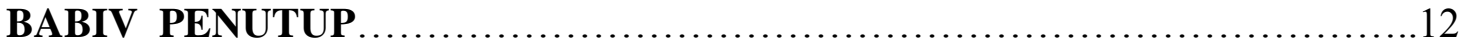

3.1 Kesimpulan ................................................ 12

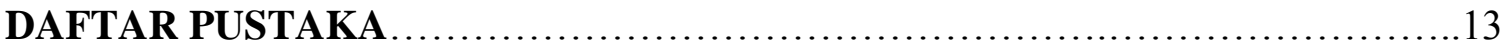




\section{BAB I \\ PENDAHULUAN}

\subsection{Latar Belakang}

Dominasi Barat atas kultur-kultur negara-negara Muslim telah mengakibatkan muncul berbagai reaksi. Dominasi tersebut terus berlangsung yang pada umumnya melalui penjajahan negara-negara Barat atas negara-negara Muslim. Dalam dunia pemikiran, pengaruh hal tersebut juga sangat terasa. Kajian para pemikir-pemikiran Islam pada umumnya terfokus kepada modernisasi, rasionalisasi, kemajuan ummat Islam dan yang semacamnya. Begitulah corak umum pemikiran pada masa modern. Hal itu tentu saja terpengaruh oleh pemikiran-pemikiran dan budaya Barat yang menjadi pusat studi ilmu pengetahuan.

Islam adalah sebuah agama yang dibawa oleh Nabi Muhammad saw, Islam meyakini agama-agama terdahulu, bahkan keberadaan agama Kristen dan agama Yahudi dibahas dalam kitab suci agama Islam, Islam menolak penuhanan apapun selain daripada Allah. Bahkan Muhammad saw sekalipun menolak penuhanan atas dirinya, sebagai agama terakhir di muka bumi maka Nabi Muhammad saw dianggap sebagai Nabi yang terakhir pula. Itulah sebabnya apabila ada orang yang mengaku menjadi nabi dan rasul setelah Nabi Muhammad saw maka akan segera dikafirkan.

Secara etimologi dalam Bahasa Arab, kata Islam berasal dari kataaslama yang berarti berserah diri, maksudnya menyerahkan diri kepada Allah. Namun kemudian berserah diri tersebut dalam Al-Qur'an harus diseimbangkan dengan perjuangan secara optimal. Islam tidak perna melarang pemeluknya untuk berpikir bahkan islam memerintahkan manusia untuk berfikir tentang segala hal agar ia bisa mengambil pelajaran dari hal-hal yang ia pikirkan. Sehingga lahirlah para pemikir dari kaum muslimin yang hasil pikirannya digolongkan kedalam para filosof islam atau pemikir islam hingga lahirlah ilmu filsafat islam. 


\section{BAB II \\ RUMUSAN MASALAH}

Filsafat merupakan hasil kreasi pemikiran maksimal manusia secara logis, sistimatis, radikal dan universal tentang tuhan, manusia, dan alam. Pemikiran tersebut muncul tidak terlepas dari kondisi dan setuasi dimana filsafat dirumuskan. Oleh karena itu kebenaran filsafat bersifat relative sesuai pola pikir dan metode filsufnya, dan kebenarannya bersifat spekulatif, karena hanya bisa dibuktikan melalui logika. Adapun filsafat islam merupakan hasil pikir para filosof muslim yang akan di bahas di makala ini yang meliputi:

1. Apa itu Filsafat Islam

2. Bagaimana Peranan Filsafat Islam itu dalam Dunia Modern

3. Bagaimana Perkembangan Filsafat Islam di Indonesia 


\section{BAB III \\ PEMBAHASAN}

\subsection{Pengertian Filsafat Islam}

\section{Apa itu Filsafat Islam}

a. Apakah yang disebut Filsafat Islam?

Dalam buku Mulyadhi Kartanegara yang berjudul Gerbang Kearifan, beliau mendiskusikan beberapa pandangan sarjana tentang istilah filsafat Islam. Ada yang megatakan bahwa Islam tidak pernah dan bisa memiliki filsafat yang independen. Adapun filsafat yang dikembangkan oleh para filosof Muslim adalah pada dasarnya filsafat Yunani, bukan filsafat Islam. Ada lagi yang mengatakan bahwa nama yang tepat untuk itu adalah filsafat Muslim, karena yang terjadi adalah filsafat Yunani yang kemudian dipelajari dan dikembangkan oleh para filosof Muslim.

Ada lagi yang mengatakan bahwa nama yang lebih tepat adalah filsafat Arab, dengan alasan bahwa bahasa yang digunakan dalam karya-karya filosofis mereka adalah bahasa Arab, sekalipun para penulisnya banyak berasal dari Persia, dan namanama lainnya seperti filsafat dalam dunia Islam.

Adapun beliau sendiri cenderung pada sebutan filsafat Islam (Islamic philosophy), dengan setidaknya 3 alasan :

1. Ketika filsafat Yunani diperkenalkan ke dunia Islam, Islam telah mengembangkan sistem teologi yang menekankan keesaan Tuhan dan syari'ah, yang menjadi pedoman bagi siapapun. Begitu dominannya Pandangan tauhid dan syari'ah ini,sehingga tidak ada suatu sistem apapun, termasuk filsafat, dapat diterima kecuali sesuai dengan ajaran pokok Islam tersebut (tawhid) dan pandangan syari'ah yang bersandar pada ajaran tauhid. Oleh karena itu ketika memperkenalkan filsafat Yunani ke dunia Islam, para filosof Muslim selalu memperhatikan kecocokannya dengan pandangan fundamental Islam tersebut, sehingga disadari atau tidak, telah terjadi "pengislaman" filsafat oleh para filosof Muslim

2. Sebagai pemikir Islam, para filosof Muslim adealah pemerhati flsafat asing yang kritis. Ketika dirasa ada kekurangan yang diderita oleh filsafat Yunani, misalanya, 
maka tanpa ragu-ragu mereka mengeritiknya secara mendasar. Misalnya, sekalipun Ibn Sina sering dikelompokkan sebagai filosof Peripatetik, namun ia tak segan-segan mengertik pandangan Aristoteles, kalau dirasa tidak cocok dan 1menggantikannnya dengan yang lebih baik. Beberapa tokoh lainnya seperti Suhrawardi, Umar b. Sahlan al-Sawi dan Ibn Taymiyyah, juga mengeriktik sistem logika Aristotetles. Sementara al-'Amiri mengeritik dengan pedas pandangan Empedokles tentang jiwa, karena dianggap tidak sesuai dengan pandangan Islam.

3. Adanya perkembangan yang unik dalam filsafat islam, akibat dari interaksi antara Islam, sebagai agama, dan filsafat Yunani. Akibatnya para filosof Muslim telah mengembangkan beberapa isu filsfat yang tidak pernah dikembangkan oleh para filosof Yunani sebelumnya, seperti filsafat kenabian, mikraj dsb.

\section{b. Lingkup Filsafat Islam}

Berbeda dengan lingkup filsafat modern, filsafat Islam, sebagaimana yang telah dikembangkan para filosof agungnya, meliputi bidang-bidang yang sangat luas, seperti logika, fisika, matematika dan metafisika yang berada di puncaknya. Seorang filosof tidak akan dikatakan filosof, kalau tidak menguasai seluruh cabang-cabang filosofis yang luas ini.

\section{c. Pandangan Filsafat yang Holistik}

Satu hal lagi yang perlu didiskusikan dalam mengenal filsafat Islam ini adalah pandangannya yang bersifat integral-holistik.Integrasi ini, sebagaimana yang telah saya jelaskan dalam karya saya yang lain Integrasi Ilmu: Sebuah Rekonstruksi Holistik, terjadi pada berbagai bidang, khususnya integrasi di bidang sumber ilmu dan klasifikasi ilmu. Filsafat Islam mengakui, sebagai sumber ilmu, bukan hanya pencerapan indrawi, tetapi juga persepsi rasional dan pengalaman mistik. Dengan kata lain menjadikan indera, akal dan hati sebagai sumber-sumber ilmu yang sah. Akibatnya terjadilah integrasi di bidang klasifikasi ilmu antara metafisika, fisika dan matematika, dengan berbagai macam divisinya. Demikian juga integrasi terjadi di bidang metodoogi dan penjelasan ilmiah. Karena itu filsafat Islam tidak hanya mengakui metode observasi, sebagai metode ilmiah, sebagaimana yang dipahami secara eksklusif dalam sains modern, tetapi juga metode 
burhani, untuk meneliti entitasentitas yang bersifat abstrak, 'irfani, untuk melakukan persepsi spiritual dengan menyaksikan (musyahadah) secara langsung entitas-entitas rohani, yang hanya bisa dianalisa lewat akal, dan terakhir bayani, yaitu sebuah metode untuk memahami teks-teks suci, seperti al-Qur'an dan Hadits. Oleh karena itu, filsafat Islam mengakui kebasahan observasi indrawi, nalar rasional, pengalaman intuitif, dan juga wahyu sebagai sumbersumber yang sah dan penting bagi ilmu.

Hal ini penting dikemukakan, mengingat selama ini banyak orang yang setelah menjadi ilmuwan, lalu menolak filsafat dan tasawuf sebagai tidak bermakna. Atau ada juga yang telah merasa menjadi filosof, lalu menyangkal keabsahan tasawuf, dengan alasan bahwa tasawuf bersifat irrasional. Atau ada juga yang telah merasa menjadi Sufi lalu menganggap tak penting filsafat dan sains. Dalam pandangan filsafat Islam yang holistik, ketiga bidang tersebut diakui sebagai bidang yang sah, yang tidak perlu dipertentangkan apa lagi ditolak, karena ketiganya merupakan tiga aspek dari sebuah kebenaran yang sama. Sangat mungkin bahwa ada seorang yang sekaligus saintis, filosof dan Sufi, karena sekalipun indera, akal dan hati bisa dibedakan, tetapi ketiganya terintegrasi dalam sebuah pribadi. Namun, seandainya kita tidak bisa menjadi sekaligus ketiganya, seyogyanya kita tidak perlu menolak keabsahan dari masing-masing bidang tersebut, karena dalam filsafat Islam ketiga unsur tersebut dipandang sama realnya.

\section{Peran Filsafat Islam dalam Dunia Modern}

\section{a. Menjawab Tantangan Kontemporer}

Pada saat ini, dalam pandangan Beliau (Mulyadhi Kartanegara), umat Islam telah dilanda berbagai persoalah ilmiah filosofis, yang datang dari pandangan ilmiah-filosofis Barat yang bersifat sekuler. Berbagai teori ilmiah, dari berbagai bidang, fisika, biologi, psikologi, dan sosiologi, telah, atas nama metode ilmiah, menyerang fondasi-fondasi kepercayaan agama. Tuhan tidak dipandang perlu lagi dibawa-bawa dalam penjelasan ilmiah. Misalnya bagi Laplace (w. 1827), kehadiran Tuhan dalam pandangan ilmiah hanyalah menempati posisi hipotesa.Dan ia mengatakan, sekarang saintis tidak memerlukan lagi hipotetsa tersebut, karena alam telah bisa dijelaskan secara ilmiah tanpa harus merujuk kepada Tuhan. Baginya, bukan Tuhan yang telah bertanggung jawab atas

keteraturan alam, tetapi adalah hukukm alam itu sendiri. Jadi Tuhan telah diberhentikan 
sebagai pemelihara dan pengatur alam. Demikian juga dalam bidang biologi, Tuhan tidak lagi dipandang sebagai pencipta hewanhewan, karena menurut Darwin (w. 1881), munculnya spesies-spesies hewan adalah karena mekanisme alam sendiri, yang ia sebut sebagai seleksi alamiah (natural selection).

Menurutnya hewan-hewan harus bertransmutasi sendiri agar ia dapat tetap survive, dan tidak ada kaitannya dengan Tuhan. Ia pernah berkata, "kerang harus menciptakan engselnya sendiri, kalau ia mau survive, dan tidak karena campur tangan sebuah agen yang cerdas di luar dirinya. Oleh karena itu dalam pandangan Darwin, Tuhan telah berhenti menjadi pencipta hewan. Dalam bidang psikologi, Freud (w. 1941) telah memandang Tuhan sebagai ilusi. Baginya bukan Tuhan yang menciptakan manusia, tetapi manusialah yang menciptakan Tuhan. Tuhan, sebagai konsep, muncul dalam pikiran manusia ketika ia tidak sanggup lagi menghadapi tantangan eksternalnya, serti bencana alam dll., maupun tantangan internalnya, ketergantungan psikologis pada figur yang lebih dominan. Sedangkan Emil Durkheim, menyatakan bahwa apa yang kita sebut Tuhan, ternyata adalah Masyarakat itu sendiri yang telah dipersonifikasikan dari nilainilai sosial yang ada.

Dengan demikian jelaslah bahwa, dalam pandangan sains modern Tuhan tidak memiliki tempat yang spesial, bahkan lama kelamaan dihapus dari wacana ilmiah. Tantangan yang lain juga terjadi di bidang lain seperti bidang spiritual, ekonomi, rkologi dll. Tentu saja tantangan seperti ini tidak boleh kita biarkan tanpa kritik, atau respons kritis dan kreatif yang dapat dengan baik menjawab tantangan-tantangan tersebut secara rasional dan elegan, dan tidak semata-mata bersifat dogmatis dan otoriter. Dan di sinilah beliau melihat bahwa filsafat Islam bisa berperan sangat aktif dan signifikan.

\section{b. Filsafat sebagai Pendukung Agama}

Berbeda dengan yang dikonsepsikan al-Ghazali, di mana filsafat dipandang sebagai lawan bagi agama, beliau (Mulyadhi Kartanegara) melihat filsafat bisa kita jadikan sebagai mitra atau pendukung bagi agama. Dalam keadaan di mana agama mendapat serangan yang gencar dari sains dan filsafat modern, filsafat Islam bisa bertindak sebagai pembela atau tameng bagi agama, dengan cara menjawab serangan sains dan filsafat modern terhadap agama secara filosofis dan rasional. Karena menurut hemat saya tantangan ilmiah-filosofis harus dijawab juga secara ilmiah-filosofis dan 
bukan semata-mata secara dogmatis. Dengan keyakinan bahwa Islam adalah agama yang menempatkan akal pada posisi yang terhormat, saya yakin bahwa Islam, pada dasarnya bisa dijelaskan secara rasional dan logis.

Selama ini filsafat dicurigai sebagai disiplin ilmu yang dapat mengancam agama. Ya, memang betul. Apaalagi filsafat yang selama ini kita pelajari bukanlah filsafat Islam, melainkan filsafat Barat yang telah lama tercerabut dari akar-akar metafisiknya. Tetapi kalau kita betul-betul mempelajari filsafat Islam dan mengarahkannya secara benar, maka filsafat Islam juga adalah sangat potensial untuk menjadi mitra filsafat atau bahwan pendukung agama. Di sini filsafat bisa bertindak sebagai benteng yang melindungi agama dari berbagai ancaman dan serangan ilmiah-filosofis seperti yang saya deskrisikan di atas.

Serangan terhadap eksistensi Tuhan, misalnya dapat dijawab dengan berbagai argumen adanya Tuhan yang telah banyak dikemukakan oleh para filosof Muslim, dari al-Kindi, Ibn Sina, Ibn Rusyd dll., seperti yang telah saya jelaskan antara lain dalam buku saya Menembus Batas Waktu. Serangan terhadap wahyu bisa dijawab oleh berbagai teori pewahyuan yang telah dikemukakan oleh banyak pemikir Muslim dari al-Ghazali, alFarabi, Ibn Sina, Ibn Taymiyyah, Ibn Rusyd, Mulla Shadra dll.

\section{Filsafat Islam di Indonesia}

\section{a. Masa Lalu}

Filsafat Islam belum begitu dikenal di Indonesia, karena memang filsfat Islam baru diperkenalkan ke publik pada tahun 70-an oleh almarhum Prof. Dr. Harun Nasution dalam bukunya yang terkenal Falsafah \& Mistisime dalam Islam, yang diterbitkan Bulan Bintang pada tahun 1973. Dalam buku ini pak Harun telah memperkenalkan 6 filosof Muslim yang terkenal yaitu al-Kindi, al-Razi, al-Farabi, Ibn Sina dan Ibn Rusyd, setelah sebelumnya ia membicarakan tentang "Kontak Pertama antara Islam dan ilmu pengetahuan serta falsafah Yunani." Dalam buku ini pak Harun dengan singkat tetapi esensial memperkenalkan biografi dan ajaran para filosof Muslim tersebut, sehingga para mahasiswa Muslim, khususnya mahasiswa IAIN di seluruh Indonesia, telah menyadari keberadaan filsafat Islam yang sebelumnya hampir tidak pernah diperkenalkan kepada mereka. Dan dengan dijadikannya buku tersebut sebagai buku wajib, maka pak Harun boleh dikata telah berhasil memperkenalkan filsafat Islam di Indonesia ini. 
Tetapi karena buku ini merupakan satu-satunya buku yang digunakan dalam matakuliah filsafat Islam selama puluhan tahun, maka timbul kesan yang keliru bahwa seakan filsafat Islam hanya menghasilkan 6 orang filosof sebagaimana yang diperkenalkan oleh Pak Harun di atas. Untunglah pada tahun 1987 Pustaka Jaya telah menerbitkan sebuah buku terjemahan yang bagus dan komprehensif tentang filsafat Islam karangan Majid Fakhry yang berjudul Sejarah Filsafat Islam, yang diterjemahkan oleh (Mulyadhi Kartanegara), sehingga dengan demikian sadarlah kita bahwa filsafat Islam telah melahirkan bukan hanya 6 filosof, sebagaimana yang telah diperkenalkan oleh Pak harun, tetapi puluhan bahkan mungkin ratusan para filosof yang tidak kalah hebatnya daripada filosof-filosof yang telah diperkenalkan sebelumnya.

Buku ini menjelaskan filsafat Islam dari sudut historis, yang meliputi paparan tentang perkembangan filsafat sebelum Islam, pada masa awal Islam, masa pertengahan dan masa modern. Dan buku ini telah menikmati posisi yang penting di universitasuniversitas Islam, sebagai buku daras yang tak ada duanya pada saat itu. Mahasiswa Muslim sangat diuntungkan dengan kehadiran karya terjemahan ini, karena ia telah banyak mengubah persepsi yang keliru tentang filsafat Islam dari sudut lingkup, rentangan waktu, ajaran dll. Dengan buku ini pula kita menjadi sadar bahwa ternyata filsafat Islam tidak berhenti pada Ibn Rusyd sebagaimana dikesankan setelah membaca buku pak harun, tetapi terus hidup dan berlangsung hingga saat ini.

\section{b. Masa Kini}

Yang di maksud dengan masa kini, adalah kurang lebih periode sepuluh tahun terkahir dari sekarang. Pada saat ini kita telah menikmati banyak informasi tentang filsafat Islam. Diterjemahkannya buku yang diedit oleh M.M. Syarif yang berjudul, History of Muslim Philosophy secara parsial ke dalam bahasa Indonesia telah memperkaya khazanah filsafat Islam di Indonesia. Tetapi tambahan informasi yang sangat signifikan terjedi setelah penerbit Mizan menerjemahkan karya besar dalam sejarah filsafat Islam yang diedit oleh Nasr dan Oliver Leaman, yang berjudul A History of Islamic Philosophy ke dalam bahasa Indonesia, dengan judul Ensiklopedia Filsafat Islam (dua jilid). Berbagai karya filosofis yang lebih spesifik (misalnya yang membahas tentang pemikiran para filosof tertentu) juga telah diterjemahkan ke dalam bahasa Indonesia, seperti The Philosophy of Mulla Sadra yang ditulis oleh Fazlur Rahman, yang 
membahas beberapa aspek dari pemikiran Mulla Shadra, atau Knowledge and Illumination, karangan Hussein Ziai, yang membicarakan secara khusus filsafat iluminasi Suhrawardi. Namun sejauh ini, informasi ini lebih bersandar pada terjemahan dari karya asing, dan bukan karangan sarjana Muslim Indonesia sendiri.

Sedikit sekali karya filsafat Islam yang ditulis oleh para penulis negeri ini. Ada misalnya buku 5 tentang Suhrawardi yang ditulis oleh sdr Amroeni, khususnya kritik Suhrawardi terhadap filsafat peripatetik, atau yang ditulis oleh M. Iqbal tentang Ibn Rusyd, sebagai bapak rasionalisme. Namun tulisan-tulisan tersebut masih bersifat studi tokoh, dan pada dasarnya diadaptasi dari sebuah tesis atau disertasi. Tidak banyak penulis Muslim Indonesia yang menulis buku pengantar terhadap filsafat Islam yang bersifat independen, kecuali pak Haidar Bagir dengan Buku Saku Filsafat Islam-nya, dan beliau (Mulyadhi Kartanegara) sendiri dengan Gerbang Kearifan-nya. 


\section{BAB IV \\ PENUTUP}

\subsection{Kesimpulan}

Dunia Islam telah berhasil membentuk suatu filsafat yang sesuai dengan prinsipprinsip agama dan keadaan masyarakat Islam sendiri. Nama Al-Kindi adalah merupakan nama yang diambil dari nama sebuah suku, yaitu : Banu Kindah. Banu Kindah adalah suku keturunan Kindah, yang berlokasi di daerah selatan Jazirah Arab dan mereka ini mempunyai kebudayaan yang tinggi.

Mengenai filsafat dan agama, Al-Kindi berusaha mempertemukan amtara kedua hal ini; Filsafat dan agama. Al-Kindi berpendapat bahwa filsafat adalah ilmu tentang kebenaran atau ilmu yang paling mulia dan paling tinggi martabatnya. Dan agama juga merupakan ilmu mengenai kebenaran, akan tetapi keduanya memiliki perbedaan. 


\section{DAFTAR PUSTAKA}

Ahmad Hanafi, Pengantar Filsafat Islam, Bulan Bintang, Jakarta : 1996

Sudarsono, Ilmu Filsafat - Suatu Pengantar, Rineka Cipta, Jakarta : 2001

Mulyadhi Kartanegara, Masa Depan Filsafat Islam “antara cita dan fakta”..Sebuah Paper

Talib, A Abdullah, filsafat umum, yayasan pendidikan, Makassar: 2007 